\title{
siRNA against presenilin 1 (PS1) down regulates amyloid $\beta 42$ production in IMR-32 cells
}

\author{
Ramesh JL Kandimalla, Willayat Yousuf Wani, Binukumar BK and Kiran Dip Gill*
}

\begin{abstract}
Background: One of the pathological hallmarks of Alzheimer's disease (AD) is the deposition of the $\sim 4 \mathrm{kDa}$ amyloid $\beta$ protein $(A \beta)$ within lesions known as senile plaques. $A \beta$ is also deposited in the walls of cerebral blood vessels in many cases of AD. A substantial proportion of the $A \beta$ that accumulates in the AD brain is deposited as Amyloid, which is highly insoluble, proteinaceous material with a $\beta$-pleated-sheet conformation and deposited extracellularly in the form of 5-10 nm wide straight fibrils. As $\gamma$-secretase catalyzes the final cleavage that releases the $A \beta 42$ or 40 from amyloid $\beta$-protein precursor (APP), therefore, it is a potential therapeutic target for the treatment of AD. $\gamma$-Secretase cleavage is performed by a high molecular weight protein complex containing presenilins (PSs), nicastrin, Aph-1 and Pen-2. Previous studies have demonstrated that the presenilins (PS1 and PS2) are critical components of a large enzyme complex that performs $\gamma$-secretase cleavage.

Methods: In this study we used RNA interference (RNAi) technology to examine the effects of small-interfering RNA (siRNA) against PS1 on expression levels of PS1 and AB42 in IMR-32 Cells using RTPCR, western blotting and immunofluorescence techniques.

Results: The results of the present study showed down regulation of PS1 and AB42 in IMR32 cells transfected with siRNA against PS1.
\end{abstract}

Conclusion: Our results substantiate the concept that PS1 is involved in $\gamma$-secretase activity and provides the rationale for therapeutic strategies aimed at influencing $A \beta 42$ production.

Keywords: Alzheimer?'?s Disease, presenilins, siRNA, Aß?ß?42, IMR-32 Cells

\section{Background}

A key step in the pathogenesis of AD is proteolysis of APP that results in the formation of the amyloid- $\beta$ protein $(A \beta)$, the principle protein component of the characteristic cerebral plaques of the disease [1]. A $\beta$ is produced from APP first by the action of $\beta$ - secretase, a membrane-tethered enzyme that resembles pepsin and other water-soluble aspartyl proteases [2]. This proteolysis leads to membrane shedding of the large luminal/ extracellular APP domain. The 99-residue membranebound remnant is then cleaved in the middle of its transmembrane region by $\gamma$-secretase, releasing $A \beta$ and again near the inner leaflet at the $\beta$ site to release the APP intracellular domain (AICD) [3]. Rare mutations in the APP gene, found in and around the $\mathrm{A} \beta$ region cause

\footnotetext{
* Correspondence: kdgill2002@yahoo.co.in

* Correspondence: kdgill2002@yahoo.co.in and Research, Chandigarh, India
}

(c) 2012 Kandimalla et al; licensee BioMed Central Ltd. This is an Open Access article distributed under the terms of the Creative

familial early-onset Alzheimer's disease (EOAD) and these mutations alter the production of $A \beta$ or its aggregation properties [4]. Several contemporaneous observations provided critical clues for the identification of the elusive $\gamma$-secretase. First, genes encoding the multi-pass membrane proteins presenilin-1 and presenilin-2 (PS1\&PS2) were discovered in a search to identify other genes associated with familial EOAD. The disease-causing missense mutations were soon found to alter how $\gamma$ -secretase cuts APP leading to increased proportions of longer, more aggregation-prone forms of $A \beta$ [5]. Second, knock out of PS- 1 dramatically reduced $\gamma$-secretase cleavage of APP [6]. Third, the types of compounds that could inhibit $\gamma$-secretase contained moieties typically found in aspartyl protease inhibitors [7]. These findings led to the identification of two conserved transmembrane aspartates in the multi-pass presenilin that are critical for $\gamma$-secretase cleavage of APP, suggesting that 
presenilins might be the responsible aspartyl proteases [8]. Presenilin is cut into two pieces, an N-terminal fragment (NTF) and a C-terminal fragment (CTF), the formation of which is gated by limiting cellular factor(s) [9]. NTF and CTF remain physically associated in a high molecular weight complex and are metabolically stable [10]. These and other results suggested that the NTFCTF heterodimer is the biologically active form $[11,12]$. The NTF and CTF each contributes one of the essential and conserved aspartates, suggesting that the $\gamma$-secretase active site might be at the interface between these two presenilin fragments. In strong support of this hypothesis, transition-state analogue inhibitors of $\gamma$ -secretase, designed to interact with the active site of the protease, bind directly to presenilin NTF and CTF $[13,14]$. However, presenilin alone is not proteolytically active. This fact, along with the requirement for other factors for presenilin NTF/CTF formation and the assembly of presenilin into large complexes, suggested that $\gamma$-secretase is composed of other subunits besides presenilins. Further, Presenilin 1 (PS1) knockout mice and inhibitor cross-linking studies have provided convincing evidence that PS1 is an essential subunit for $\gamma$ secretase processing [15]. Recently, small interfering RNA (siRNA) has been found to be important in regulating protein expression in organisms varying from plants to mammals [16]. By activating a sequence-specific RNA degradation process, siRNA post transcriptionally inhibits protein expression of the specific gene $[17,18]$. We exploited siRNA technology to understand the regulation of $\gamma$-secretase by presenilin- 1 and its impact on $A \beta 42$ production in IMR-32 neuronal cell line. The results showed that there was PS1 down regulation and lesser $A \beta 42$ production, suggesting PS1 is involved in $\gamma$-secretase activity and provides the rationale for therapeutic strategies aimed at influencing $A \beta$ production.

\section{Methods}

\subsection{IMR-32 cell culture}

Human neuroblastoma IMR-32 cells were obtained from NCCS, Pune, India and maintained at $37^{\circ} \mathrm{C}$ in an atmosphere of $95 \%$ air and $5 \% \mathrm{CO}_{2}$ in Eagle's minimum essential medium supplemented with $2 \mathrm{mM}$ L-glutamine and Earle's BSS, $1.5 \mathrm{~g} / \mathrm{L}$ bicarbonate, $0.1 \mathrm{mM}$ nonessential amino acids, $1.0 \mathrm{mM}$ Sodium pyruvate and $10 \%$ heat-inactivated fetal bovine serum. Media was changed every two days. Passage was done in 1:3 ratios and doubling time was 24 Hours.

\section{2 siRNA transfection against PS1}

In a six well tissue culture plate, $2 \times 10^{5}$ cells were seeded per well in $2 \mathrm{ml}$ antibiotic-free normal growth medium supplemented with FBS. The cells were incubated at $37^{\circ} \mathrm{C}$ in a $\mathrm{CO}_{2}$ incubator until the cells were $60-80 \%$ confluent for $18-24$ hours. Transfection of PS1 siRNA (50 pmoles, 75 pmoles and 100 pmoles siRNA) and control siRNA duplex was done with the transfection reagent after checking the cell viability with the trypan blue and the cells were incubated for 5-7 hours at $37^{\circ} \mathrm{C}$ in a $\mathrm{CO}_{2}$ incubator. Then $1 \mathrm{ml}$ of normal growth medium was added, containing 2 times the normal serum and antibiotics concentration $(2 \times$ normal growth medium) without removing the transfection mixture and the cells were incubated for an additional 18-24 hours. After incubation, media was aspirated and replaced with $1 \mathrm{X}$ normal growth medium and incubated for 48 hours. After 48 hours cells were used for RNA (Taurus Scientific) and protein isolation, used for RTPCR and western blotting analysis respectively.

\subsection{Semi-Quantitative PCR amplification}

Expression of PS1 after transfecting IMR-32 cells with siRNA against PS1 was evaluated by PCR analysis using sequence specific primers corresponding to the sequence in the open reading frame. $10 \mu \mathrm{l}$ PCR mixture was prepared in $1 \times$ PCR buffer consisting of 1 unit of Taq polymerase, $2 \mu \mathrm{M}$ of each primer for GAPDH and PS1 along with $200 \mu \mathrm{M}$ of each dNTP. For amplification of PS 1 and GAPDH, cDNA products $(1 \mu \mathrm{l})$ were subjected to reverse transcriptase PCR analysis on a gradient thermal cycler instrument (Eppendorff, Germany). PCR cycle for PS1 and control siRNA comprised of initial denaturation at $94^{\circ} \mathrm{C}$ for $2 \mathrm{~min}$. The amplification was then carried out for 35 cycles consisting $45 \mathrm{sec}$ each for $94^{\circ} \mathrm{C}$ (denaturation), $62^{\circ} \mathrm{C}$ (annealing) and $72^{\circ} \mathrm{C}$, 1 min (elongation). Final extension was done at $72^{\circ} \mathrm{C}$ for 10 min. PCR cycle of GAPDH, which was used as internal control, comprised of initial denaturation at $94^{\circ} \mathrm{C}$ for $2 \mathrm{~min}$. The amplification was then carried out for 35 cycles consisting $45 \mathrm{sec}$ each for $94^{\circ} \mathrm{C}$ (denaturation), $56.8^{\circ} \mathrm{C}$ (annealing) and $72^{\circ} \mathrm{C}, 1 \mathrm{~min}$ (elongation). Final extension was done at $72^{\circ} \mathrm{C}$ for $10 \mathrm{~min}$. Densitometric analysis of the products was done using SCION IMAGE software (Scion Image Corporation, Fredrick, MD, USA) to compare the relative mRNA expression of PS1 gene at various concentrations of PS1 siRNA duplex.

\subsection{Immunoblotting}

\section{Immuno detection of PS 1}

Following SDS-PAGE (12\%), proteins were transferred to NC membrane with semi dry apparatus (Bio Rad) using transfer buffer [25 mM Tris, $192 \mathrm{mM}$ glycine, 20\% ( $\mathrm{vol} / \mathrm{vol}$ ) methanol, $\mathrm{pH}$ 8.3]. The blots were incubated with $5 \%$ non fat dried milk for at least $2 \mathrm{~h}$ and then washed three times for 10 min each with PBS plus $0.1 \%$ Tween-20. Blots were incubated for $2.5 \mathrm{~h}$ at room temperature with anti PS1antibody (diluted 1:250 in PBS) 
(Santa cruz Biotechnology, Inc, USA). The primary antibody was removed, and the blots were washed three times for 10 min each with PBS plus $0.1 \%$ Tween-20. The blots were then incubated in horseradish peroxidase-labeled goat anti-rabbit IgG (diluted 1:5,000 in PBS) for $45 \mathrm{~min}$ at room temperature. After washing the membrane for at least 1 hour, the proteins were visualized by diaminobenzidine (DAB) from Bangalore Genei, India The densitometric analysis of the protein bands was carried out using SCION IMAGE software (Scion Image Corporation, Fredrick, MD, USA) to compare the relative expression of proteins.

\section{Immuno detection of $A \beta 42$}

Following SDS-PAGE (16\%), proteins were transferred to NC membrane with semi dry apparatus (Bio Rad) using transfer buffer [25 mM Tris, $192 \mathrm{mM}$ glycine, 20\% (vol/vol) methanol, pH 8.3]. The blots were incubated with $5 \%$ non fat dried milk for at least $2 \mathrm{~h}$ and then washed three times for $10 \mathrm{~min}$ each with PBS plus $0.1 \%$ Tween-20. Blots were incubated for $2.5 \mathrm{~h}$ at room temperature with anti $A \beta 42$ antibody (diluted 1:250 in PBS) (Santa cruz Biotechnology, Inc, USA). The primary antibody was removed, and the blots were washed three times for 10 min each with PBS plus $0.1 \%$ Tween-20. The blots were then incubated in horseradish peroxidase-labeled goat anti-rabbit IgG (diluted 1:5,000 in PBS) for $45 \mathrm{~min}$ at room temperature. After washing the membrane for at least 1 hour, the proteins were visualized by diaminobenzidine (DAB), from Bangalore Genei, India. The densitometric analysis of the protein bands was carried out using SCION IMAGE software (Scion Image Corporation, Fredrick, MD, USA) to compare the relative expression of proteins.

Immunofluorescence staining of PS1 and $A \beta 42$

IMR-32 cells were transfected with PS1 siRNA as described earlier and cells were fixed with the 1:1 Acetone/Methanol fixative for 20 minutes at $20^{\circ} \mathrm{C}$. After 20 minutes fixative was aspirated and washed three times with the $1 \mathrm{X}$ PBS and proceeded for immunostaining. For immunostaining, fixed cells were blocked in the blocking buffer for 60 minutes at $37^{\circ} \mathrm{C}$. After 60 minutes blocking buffer was aspirated and incubated with the anti PS1, anti A 342 (1:50 dilutions) (Santa cruz Biotechnology, Inc, USA) for 24 hours at $4^{\circ} \mathrm{C}$. After 24 hours incubation, cells were rinsed three times with $1 \mathrm{X}$ PBS and incubated with FITC labelled secondary antibody (1:50 dilutions) for 2 hours in dark at $37^{\circ} \mathrm{C}$. The cells were visualized under the fluorescence microscope and the images were recorded.

\section{Results}

3.1 Effect of siRNA on the expression of presenilin 1 (PS1) gene in IMR-32 cells determined by RT-PCR

After attaining 60-80\% confluency, IMR-32 cells were transfected with varying concentrations (50 pmoles, 75 pmoles, and 100 pmoles) of PS1 siRNA and 100 pmoles of control or scrambled siRNA. Semiquantitative PCR analysis of PS1 showed reduction in PS1mRNA in IMR32 cells with increasing concentration of PS1 siRNA with maximum reduction at 100 pmoles (Figure 1).

\subsection{Effect of siRNA on the content of PS1 peptide in IMR- 32 cells}

Western blotting analysis of PS1 showed a decreased protein expression with increase in concentration of PS1 siRNA. In other words there was a dose dependent decrease in PS1 protein levels with increased concentration of PS1 siRNA(Figure 2).

\subsection{Effect of PS1 siRNA on $A \beta 42$ production in IMR-32 cells}

A $\beta 42$ expression was studies were carried out using western blotting, after IMR32 cells were transfected with the PS1 siRNA, 50 pmoles PS1 siRNA was able to reduce the $A \beta 42$ expression, but at 75 pmoles and 100 pmoles of PS1 siRNA the expression was completely reduced (Figure 3 ).

\subsection{Immunofuorescence analysis of PS1 and A $\beta 42$}

In order to confirm the results obtained from western blotting further immunoflourescence was carried out after transfecting IMR-32 cells with the control siRNA and PS1 siRNA in the same concentrations (50 pmoles, 75 pmoles and 100 pmoles) using antibodies against PS1 and A $\beta 42$. As is evident from Figure 4 and 5, the expression levels of PS1and A $\beta 42$ after transfection almost ceased at 75 and 100 pmole concentration. Therefore, down regulation of PS1 using PS1 siRNA results in down regulation of $\mathrm{A} \beta 42$ as well.

\section{Discussion}

$\gamma$-Secretase activity is responsible for the cleavage of the transmembrane domain of the amyloid precursor protein (APP), releasing the amyloid peptide $A \beta$ and the APP intracellular domain. $A \beta$ is a major component of the amyloid plaques characteristic of Alzheimer's disease. Presenilins (PS1 and PS2) appear to be essential for $\gamma$-secretase cleavage and form an essential part of the $\boldsymbol{\gamma}$-secretase complex. PS1 knockout markedly inhibits $\gamma$-secretase cleavage [19], whereas a PS2 knockout has no apparent effect on $\gamma$-secretase activity [20], probably owing to compensation by the more widely expressed PS1. Recent studies have identified PS1 as a part of $\gamma$ - secretase complex. To test the role of PS1 in A $\beta 42$ production and find out new drug and gene therapy for $\mathrm{AD}$, in the present study IMR-32 cells were transfected with siRNA against PS1gene, and in order to interfere with transcription of PS1 gene, and then determined the levels of PS1 mRNA, PS1 and 


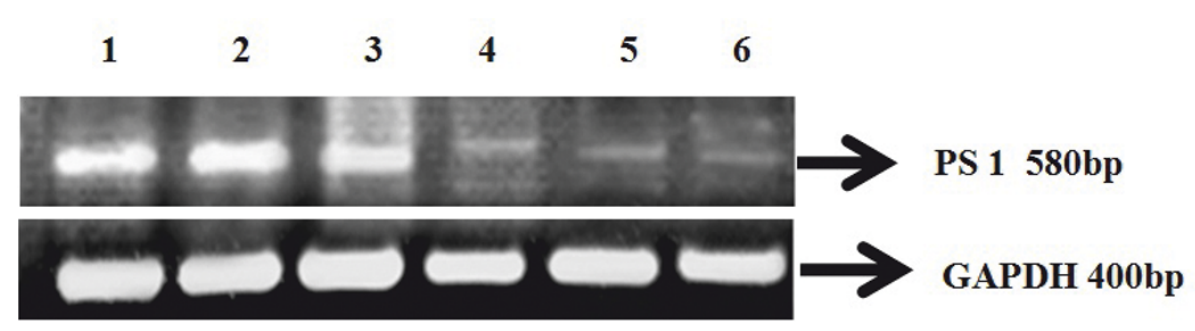

(a)

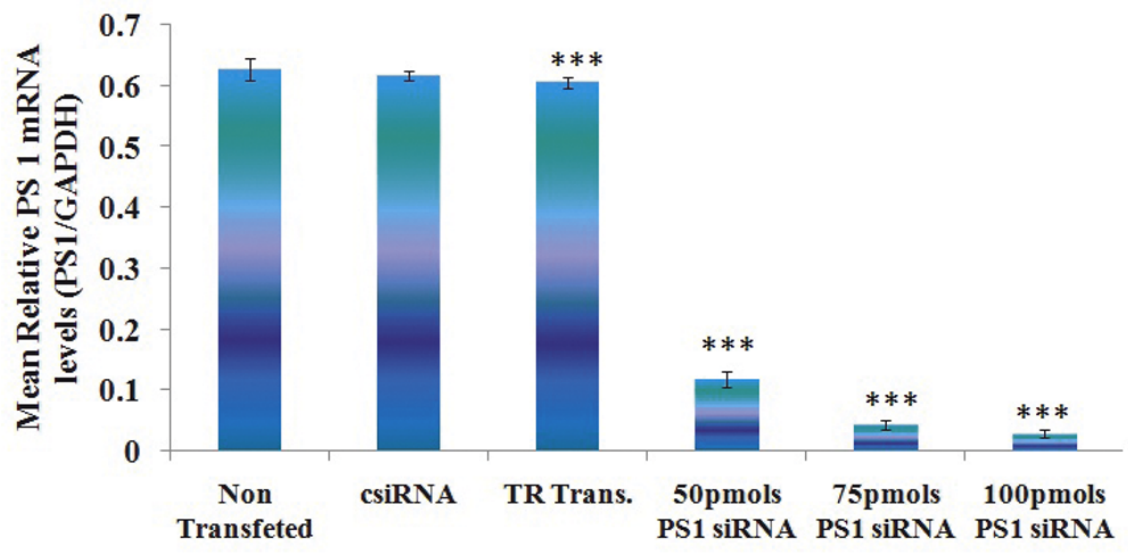

(b)

Figure 1 RT-PCR analysis of PS1 (a) agarose gel electrophoresis and (b) densitometric analysis. Values are mean \pm SD ( $N=5)$ Lane 1 : Non siRNA transfected IMR-32 cells; Lane 2: Control siRNA transfected IMR-32 cells; Lane 3: Transfection Reagent transfected IMR-32 cells; Lane 4: 50 pmoles PS1 siRNA transfected IMR-32 cells; Lane 4: 75 pmoles PS1 siRNA transfected IMR-32 cells; Lane 5: 100 pmoles PS1 siRNA transfected IMR-32 cells. Values are mean $\pm S D(N=5) .{ }^{* * *} p<0.001$ significantly different from csiRNA.

A 342 protein levels. Our data demonstrated that suppression of PS1 gene in IMR-32 cells decreased the production of A $\beta 42$, suggesting that PS1 contributes to $\gamma$ secretase activity. The final step of $A \beta$ biogenesis is the processing of CTF $\gamma$ by $\gamma$-secretase within the $\beta$ APP transmembrane domain. With the single exception of the Swedish $\beta$ APP mutation (K670 to N and M671 to L) all the identified changes linked to early onset familial Alzheimer disease (FAD) affect $\gamma$-secretase processing to specifically increase the levels of $A \beta 42$ [21]. To date over 50 FAD linked mutations in the chromosome 14 encoded presenilin 1 (PS1) have been identified, and several more in presenilin 2 (PS2). Previous studies have identified several proteins that bind PS1 but their roles at least partly appear to be related to the function of PS1, other than $\gamma$ secretase activity such as regulation of apoptosis and calcium signaling [22]. On the other hand studies on mutant presenilins in transgenic animals have shown increase in the relative level of $A \beta 42$ production [23,24]. The blocking expression of PS1 protein using siRNA results in a loss of $\gamma$-secretase activity. In this study, we wanted to know whether suppression of PS1 could regulate $\gamma$-secretase activity in IMR-32 cells and regulate $A \beta 42$ production. The cell line was characterized by the increased $\gamma$-secretase activity and $\mathrm{A} \beta 42$ production in $\mathrm{AD}$ [25]. The fact that PS1 is at least partially limiting the A $\beta 42$ production suggests that $\gamma$-secretase is indeed a complex including PS1 and the complex activity which can be increased by the expression or reinforcement of any one of its components. A $\beta P P$ is cleaved by $\beta$-secretase to CTF $\beta$, which is subsequently processed by $\gamma$ secretase to $A \beta 40 / 42$ and CTF $\gamma 50$. A 79-residue fragment between the two cleavage sites has not yet been detected. Multiple studies indicate that $\gamma$-secretase is a large multisubunit enzyme [26].

Based on mutagenesis and inhibitor cross-linking studies, it has been suggested that PS1 constitute the catalytically active subunit of $\gamma$-secretase. However, PS1 is not sufficient for $\gamma$-secretase activity in vitro and multiple subunits have been identified that are essential for generation of the active enzyme. Several of these subunits are apparently limiting for $\gamma$-secretase activity in the cell. Since increase in $A \beta 42$ is consistently linked to AD pathogenesis [26], the finding that levels of PS1 can regulate the production of this fragment makes it important candidate for evaluation in AD. The reduction in 

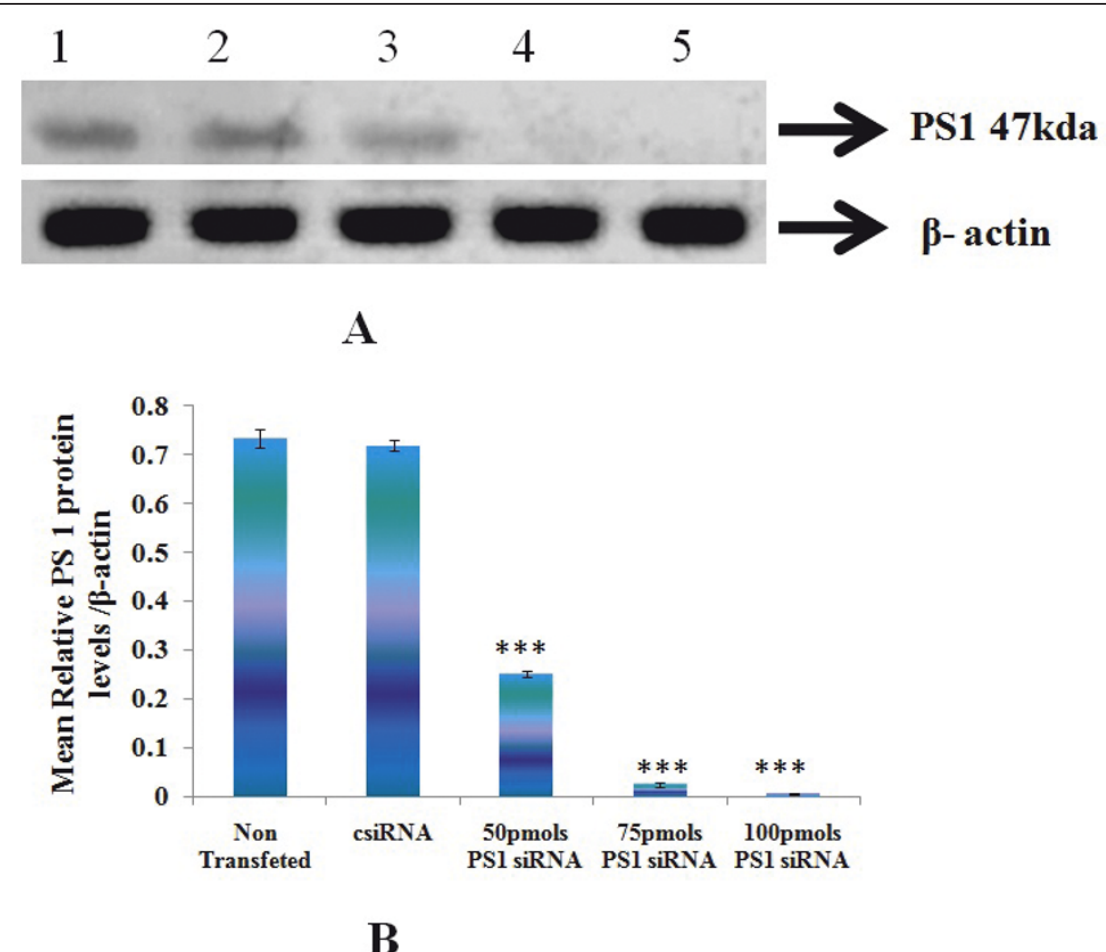

Figure 2 Effect of PS1 siRNA on the protein levels of PS1 (a) Immunoblot analysis of PS1 (b) densitometric analysis. $60 \mu \mathrm{g}$ proteins from IMR 32 cells after PS1 transfection at different concentrations were subjected to westren blot analysis using an anti PS1 antibody (1:250 dilutions). Lane 1: Non siRNA Transfected IMR-32 Cells; Lane 2: Control siRNA; Lane 3: 50 pmoles PS1siRNA; Lane 4: 75 pmoles PS1 siRNA; Lane 5: 100 pmoles PS1 siRNA. Values are mean \pm SD $(N=5) .{ }^{* * *} p<0.001$ significantly different from csiRNA.

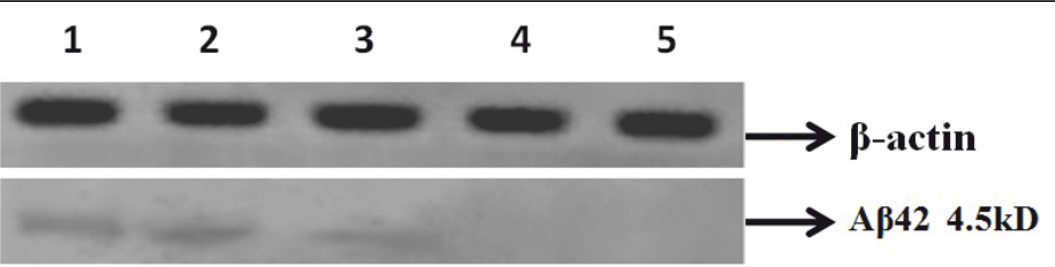

A

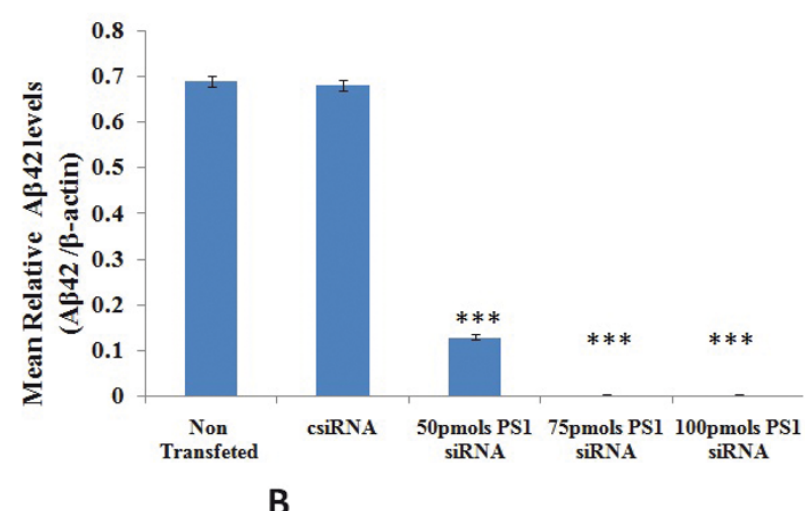

Figure 3 Effect of PS1 siRNA on the protein levels A $\beta 42$ (a) Immunoblot analysis of A $\mathbf{\beta} 42$ (b) densitometric analysis. $60 \mu \mathrm{g}$ proteins of IMR 32 cells after PS1 transfection at different concentrations were subjected to western blot analysis using anti A 342 antibody (1:250 dilutions). Lane 1: Non siRNA Transfected IMR-32 Cells; Lane 2: Control siRNA; Lane 3: 50 pmoles PS1siRNA; Lane 4: 75 pmoles PS1 siRNA; Lane 5:100 pmoles PS1 siRNA. Values are mean \pm SD $(N=5) .{ }^{* * *} p<0.001$ significantly different from csiRNA. 


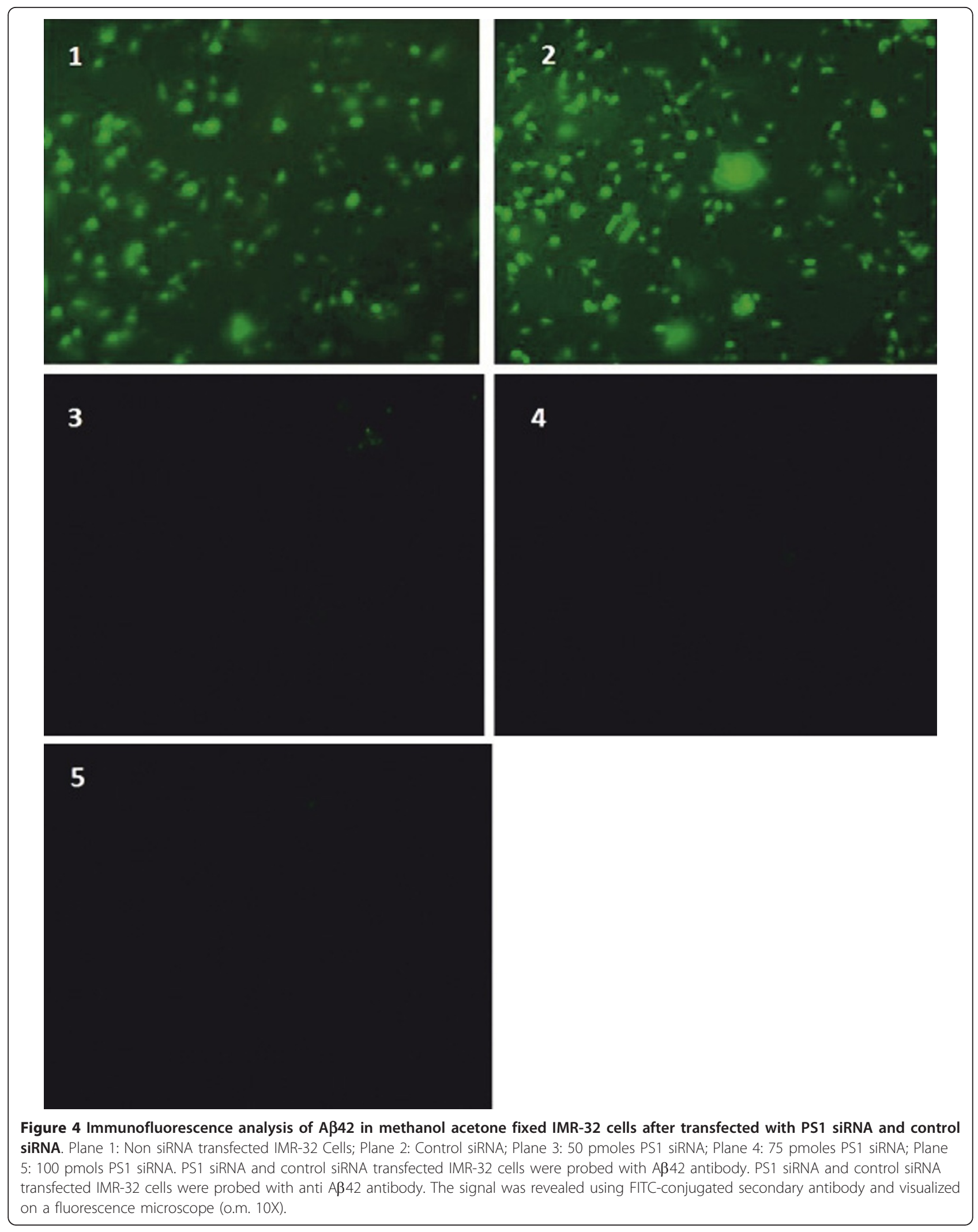




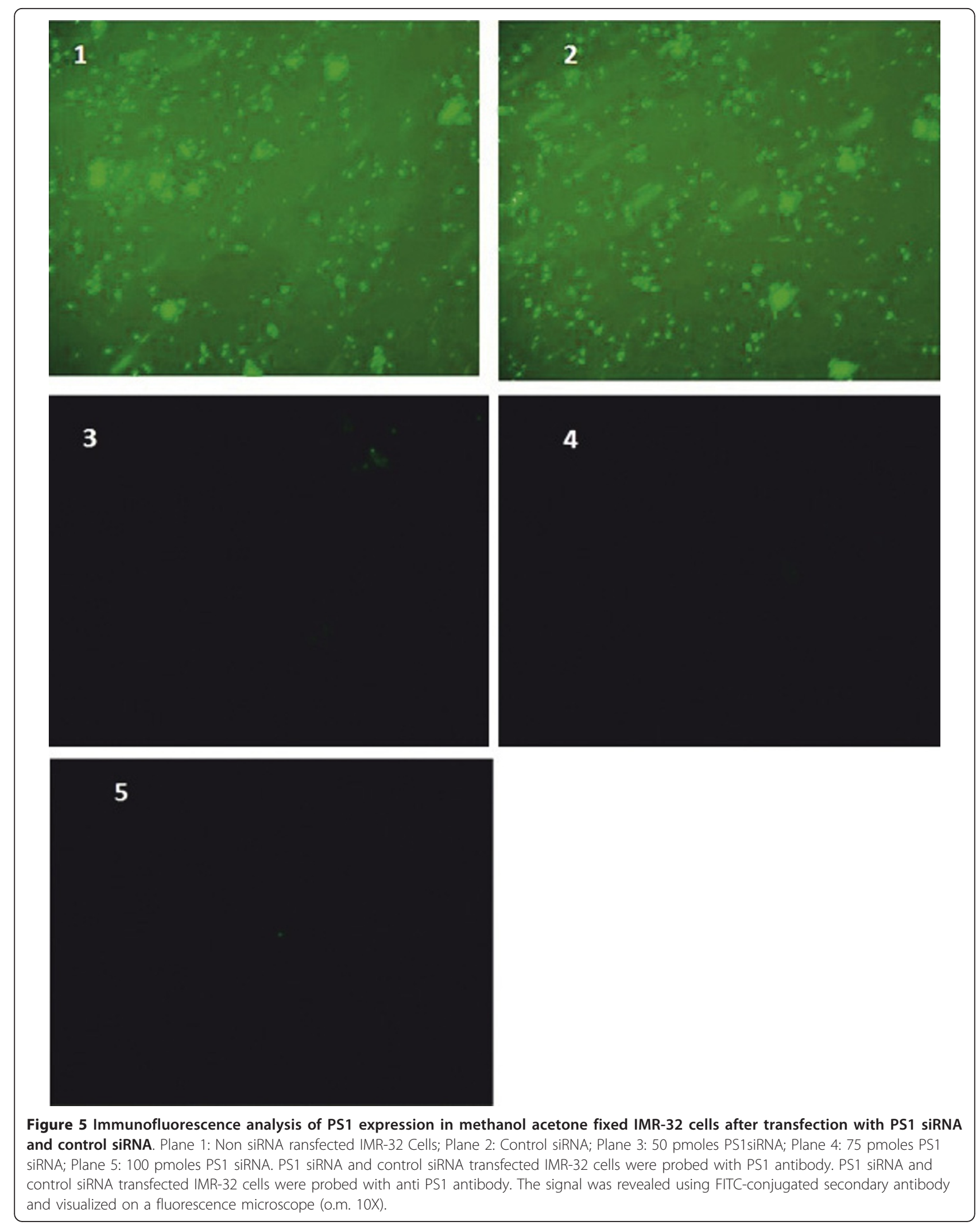


the relative $A \beta 42$ levels is consistent with the observed inhibition of $\gamma$-secretase with a variety of inhibitors [27], which may play an important protective function in the brain. Thus, the reinforcement of $\gamma$-secretase activity may be one of the reasons that cause AD. Alternatively, the increase in $A \beta 42$ may be a marker of the reinforcement of $\gamma$-secretase activity, which may result in the reinforcement of function of a number of $\gamma$-secretase substrates including Notch.

\section{Conclusion}

So in the present study we have shown that siRNA against PS1 down regulates amyloid beta 42 production in IMR32 cells. Taken together the results of the present study suggest that in pathogenic condition we may target PS1 for anti-amyloidogenic therapy in Alzheimer's disease as IMR32 is an AD featured cell line. These results also reconfirm a role of PS1 in $\gamma$-secretase activity.

\section{Abbreviations}

A $\beta$ : Amyloid $\beta$; AD: Alzheimer disease; APP: amyloid precursor protein; CTF: C-Terminal fragment; FAD: Familial Alzheimer disease; NTF: N-Terminal fragment; PS: presenilin; siRNA: small-interfering RNA.

\section{Acknowledgements}

This work was supported by grants from the Indian council of Medical Research (ICMR), New Delhi, India.

\section{Authors' contributions}

RJLK planned the experimental design, analyzed and interpreted data, and drafted the manuscript. WYW acquired and interpreted data and drafted the manuscript. BKBK analyzed data. KDG planned the experimental design and analyzed and interpreted data. All authors read and approved the final manuscript.

\section{Competing interests}

We don't have any potential conflicts regarding all financial and material support for this research.

Received: 20 November 2011 Accepted: 3 January 2012

Published: 3 January 2012

\section{References}

1. Goedert M, Spillantini MG: A century of Alzheimer's disease. Science 2006, 314:777-781.

2. Cole $S L$, Vassar $R$ : The role of amyloid precursor protein processing by BACE1, the beta-secretase, in Alzheimer disease pathophysiology. J Biol Chem 2008, 283:29621-29625.

3. Weidemann A, Eggert S, Reinhard FB, Vogel M, Paliga K, Baier G, Masters CL, Beyreuther K, Evin G: A novel epsilon-cleavage within the transmembrane domain of the Alzheimer amyloid precursor protein demonstrates homology with Notch processing. Biochemistry 2002, 4:12825-2835.

4. Tanzi RE, Bertram L: Twenty years of the Alzheimer's disease amyloid hypothesis: a genetic perspective. Cell 2005, 120:545-555.

5. Hardy J: The Alzheimer family of diseases: many etiologies, one pathogenesis? Proc Natl Acad Sci USA 1997, 94:2095-2097.

6. De Strooper B, Saftig P, Craessaerts K, Vanderstichele H, Guhde G, Annaert W, Von Figura K, Van Leuven F: Deficiency of presenilin-1 inhibits the normal cleavage of amyloid precursor protein. Nature 1998, 391:387-390

7. Wolfe MS, Xia W, Moore CL, Leatherwood DD, Ostazewski B, Rahmati T, Donkor IO, Selkoe DJ: Peptidomimetic probes and molecular modeling suggest that Alzheimer's gamma-secretase is an intramembranecleaving aspartyl protease. Biochemistry 1999, 38:4720-4727.
8. Wolfe MS, Xia W, Ostaszewski BL, Diehl TS, Kimberly WT, Selkoe DJ: Two transmembrane aspartates in presenilin-1 required for presenilin endoproteolysis and gamma-secretase activity. Nature 1999, 398:513-517.

9. Thinakaran $\mathrm{G}$, Harris $\mathrm{CL}$, Ratovitski $\mathrm{T}$, Davenport F, Slunt $\mathrm{HH}$, Price DL, Borchelt DR, Sisodia SS: Evidence that levels of presenilins (PS1 and PS2) are coordinately regulated by competition for limiting cellular factors. $J$ Biol Chem 1997, 272:28415-28422.

10. Ratovitski T, Slunt HH, Thinakaran G, Price DL, Sisodia SS, Borchelt DR: Endoproteolytic processing and stabilization of wild-type and mutant presenilin. J Biol Chem 1997, 272:24536-24541.

11. Yu G, Chen F, Levesque G, Nishimura M, Zhang DM, Levesque L, Rogaeva $E$, Xu D, Liang Y, Duthie M, St George-Hyslop PH, Fraser PE: The presenilin 1 protein is a component of a high molecular weight intracellular complex that contains beta-catenin. J Biol Chem 1998, 273:16470-16475.

12. Laudon $\mathrm{H}$, Mathews PM, Karlstrom H, Bergman A, Farmery MR, Nixon RA, Winblad B, Gandy SE, Lendahl U, Lundkvist J, Naslund J: Co-expressed presenilin $1 \mathrm{NTF}$ and CTF form functional gamma-secretase complexes in cells devoid of full-length protein. J Neuro Chem 2004, 89:44-53.

13. Li YM, Xu M, Lai MT, Huang Q, Castro JL, DiMuzio-Mower J, Harrison T, Lellis C, Nadin A, Neduvelil JG, Register RB, Sardana MK, Shearman MS, Smith AL, Shi XP, Yin KC, Shafer JA, Gardell SJ: Photoactivated gammasecretase inhibitors directed to the active site covalently label presenilin 1. Nature $2000,405: 689-694$.

14. Esler WP, Kimberly WT, Ostaszewski BL, Diehl TS, Moore CL, Tsai JY, Rahmati T, Xia W, Selkoe DJ, Wolfe MS: Transition-state analogue inhibitors of gamma-secretase bind directly to presenilin-1. Nat Cell Biol 2000, 2:428-434.

15. Wolfe MS: Gamma-Secretase in biology and medicine. Semin Cell Dev Biol 2009, 20:219-224.

16. Agarwal N, Dasaradhi PV, Mohmmed A, Malhotra P, Bhatnagar RK, Mukherjee SK: RNA interference: biology, mechanism, and applications. Microbiol. Mol Biol Rev 2003, 67:657-685.

17. Miller VM, Xia H, Marrs GL, Gouvion CM, Lee G, Davidson BL, Paulson HL: Allele-specific silencing of dominant disease genes. Proc Natl Acad Sci USA 2003, 100:7195-7200.

18. Miller VM, Gouvion CM, Davidson BL, Paulson HL: Targeting Alzheimer's disease genes with RNA interference: an efficient strategy for silencing mutant alleles. Nucleic Acids Res 2004, 32:661-668.

19. De Strooper B, Annaert W, Cupers P, Saftig P, Craessaerts K, Mumm JS, Schroeter EH, Schrijvers V, Wolfe MS, Ray WJ, Goate A, Kopan R: A presenilin-1-dependent gamma-secretase-like protease mediates release of Notch intracellular domain. Nature 1999, 398:518-522.

20. Herreman A, Hartmann D, Annaert W, Saftig P, Craessaerts K, Serneels L, Umans L, Schrijvers V, Checler F, Vanderstichele H, Baekelandt V, Dressel R, Cupers P, Huylebroeck D, Zwijsen A, Van Leuven F, De Strooper B: Presenilin 2 deficiency causes a mild pulmonary phenotype and no changes in amyloid precursor protein processing but enhances the embryonic lethal phenotype of presenilin 1 deficiency. Proc Natl Acad Sci USA 1999, 96:11872-11877.

21. Hardy J, Selkoe DJ: The amyloid hypothesis of Alzheimer's disease: progress and problems on the road to therapeutics. Science 2002, 297:353-356.

22. Yan R, Bienkowski MJ, Shuck ME, Miao H, Tory MC, Pauley AM, Brashier JR, Stratman NC, Mathews WR, Buhl AE, Carter DB, Tomasselli AG, Parodi LA Heinrikson RL, Gurney ME: Membrane-anchored aspartyl protease with Alzheimer's disease beta-secretase activity. Nature 1999, 402:533-537.

23. Hardy J: Amyloid, the presenilins and Alzheimer's disease. Trends Neuro sci 1997, 20:154-159.

24. Scheuner D, Eckkman C, Jensen M, Song X, Citron M, Suzuki N, Hardy J, Hutton M, Kukull W, Larson E, Levy-Lahad E, Viitanen M, Peskind E, Poorkaj P, Schellenberg G, Tanzi R, Wasco W, Lannfelt L, Selkoe D, Younkin S: Secreted amyloid beta-protein similar to that in the senile plaques of Alzheimer's disease is increased in vivo by the presenilin 1 and 2 and APP mutations linked to familial Alzheimer's disease. Nat Med 1996, 2:864-870

25. Guo Q, Xie J, Chang X, Du H: Prostate apoptosis response-4 enhances secretion of amyloid beta peptide 1-42 in human neuroblastoma IMR-32 cells by a caspase-dependent pathway. J Biol Chem 2001, 276:16040-16044.

26. Golde TE, Younkin SG: Presenilins as therapeutic targets for the treatment of Alzheimer's disease. Trends Mol Med 2001, 7:264-269. 
27. Wolfe MS, Citron M, Diehl TS, Xia W, Donkor IO, Selkoe DJ: A substrate based difluoro ketone selectivity inhibits Alzheimer's gamma-secretase activity. J Med Chem 1998, 41:6-9.

doi:10.1186/1423-0127-19-2

Cite this article as: Kandimalla et al:: siRNA against presenilin 1 (PS1)

down regulates amyloid $\beta 42$ production in IMR-32 cells. Journal of

Biomedical Science 2012 19:2.

Submit your next manuscript to BioMed Central and take full advantage of:

- Convenient online submission

- Thorough peer review

- No space constraints or color figure charges

- Immediate publication on acceptance

- Inclusion in PubMed, CAS, Scopus and Google Scholar

- Research which is freely available for redistribution

Submit your manuscript at 